\title{
Updated Review Costen's Syndrome: Clinical Relationship between Dentistry and Medicine
}

\author{
Caio Bortolociㄹ ${ }^{1}$ Ana Beatriz Moimáz ${ }^{2}$, and Mirto Prandini ${ }^{3 *}$ \\ ${ }^{1}$ Departament of Odontologia, UNOESTE, Universidade do Oeste Paulista - Presidente Prudente, São Paulo, Brazil \\ ${ }^{2}$ Departament of Medical, UNIFAI, Centro Universitário de Adamantina - Adamantina, São Paulo, Brazil \\ ${ }^{3}$ Departament of Neurology and Neurosurgery UNIFESP, Universidade Federal do Estado de São Paulo, São Paulo, Brazil
}

Submission: May 14, 2020; Published: June 11, 2020

*Corresponding author: Mirto Prandini, Departament of Neurology and Neurosurgery UNIFESP, Universidade Federal do Estado de São Paulo, São Paulo, Brazil

\section{Abstract}

Introduction: Costen syndrome is a term used to describe the functional and structural changes that occur involving the temporomandibular articulation causing a variable symptomatology including hemi cranial pain and masticatory disturbances.

Objectives: In view of the and importance of the issue, the incidence over $50 \%$ of populations and variability of symptoms we decided to update some new information regarding its etiology and treatments proposed.

Methods: A research was carried out based on papers published in English and Portuguese literature from 2005 to 2017.

Conclusion: A series of procedures and new therapies were presented. However, we think that even after decades, Costen syndrome still remains one obscure issue.

\section{Introduction}

Costen's syndrome was first named and described in 1934 by James Costen. Based on 11 cases, he was the first to suggest that changes in dental conditions were responsible for several symptoms from otological origin. The author found the occurrence of cases that presented symptoms in the region of the temporomandibular joints (TMJ) as pain of musculoskeletal origin, crackling and crackling), otological symptoms such as tinnitus and difficulties in opening the mouth as well as significant cause of unilateral headache [1]. Symptomatology goes beyond a structural relationship, as it encompasses knowledge from more than one specialty in the health field, thus making treatment with only one specialist difficult. Although several conditions can determine its advent, there is basically a disharmony of the stomatognathic system caused by several factors such as the consequences of tooth loss poorly adapted prostheses, parafunctional habits such as bruxism, , postural alteration of the jaw and neck in addition to psychological factors that cause an increase in muscle activity causing spasms and fatigue. Quinto 1999 [2].

\section{Methodology}

This bibliographic review was carried out by searching online databases, such as Scielo, PubMed, using the keywords syndrome, Costen and temporomandibular disorder (TMD), from 2005 to 2017, in English and Portuguese idioms, totaling 20 articles.

\section{Etiology}

James Costen in 1934, based in embryology and anatomophysiology studies in order to elucidate a more accurate diagnosis for patients with complaints affecting the temporomandibular region. The close anatomical and functional relationship between TMJ structures and those of the auditory system provides a basis for inducing a causal relationship between TMDs and auditory function disorders Thus, for the temporomandibular joint to be able to functioning harmoniously, it is necessary that dental occlusion and neuromuscular balance act in agreement [3]. Pinto [4] reported an anatomical explanation for such a wide range of multidisciplinary symptoms. It is mentioned the existence of a 
link between a ligament that communicates the condyle and articular disc with the middle ear, lateral to the chorda tympani nerve [4]. Anatomically, the TMJ region is adjacent to the ear, requiring a proper positioning inside the mandibular fossa. Therefore, in cases of occurrence of any external or internal stimulus that affects this harmony joint leading to its displacement, this will result in damage to nearby structures causing symptomatic consequences to the individual [5]. Therefore, as already observed, it can be concluded that the etiology of Costen's Syndrome is multifactorial, since several aspects are present, as tooth loss, poorly adapted prostheses, dental wear, deficient restorations, bruxism and parafunctional habits (nail biting, finger sucking, biting objects) both generating disocclusion. It also may be mentioned the presence of psychological factors that cause increased activity, or muscle tone, which leads to the development of muscle spasms [6].

\section{Clinics}

The variability of etiological factors resulted in a clinical picture quite extensive, subject to great variability. Based on a literature review conducted in 2010 by Barreto, we can point out some more frequent signs and symptoms of TMD. Complaints such as clicks, ear fullness (muffled hearing sensation), tinnitus, vertigo, vertical decrease in occlusion (measure of the distance between two points on the face, and the most common symptom is pain with different characteristics, such as otalgia, myalgia and headache. There are, therefore, several differential diagnoses [7]. The link between temporomandibular disorders and craniofacial symptoms is increasingly quite evident, providing to dentistry professionals the possibility to investigate and put into practice the knowledge acquired in this area. Badim describes that TMJ dysfunction is any change in normal movement, whether with or without symptoms [8].

\section{Diagnostic}

It is known that the diagnosis of TMD is syndromic, that is, it is necessary a set of signs and symptoms that define the clinical manifestations of the affected region, regardless of the etiology. Costen's Syndrome has a high prevalence since epidemiological research has shown that more than $50 \%$ of the population has had at least one or more signs of TMD. Due to its wide range of factors, it has not yet been possible to establish a standardized diagnosis [9]. With regard to the diagnosis of TMD, there is still no reliable method of diagnosis and measurement of the presence and severity of TMD. Nevertheless, for the diagnosis of individual cases, anamnesis remains the most important step in formulating the initial diagnostic impression. The anamnesis requires a complete identification of predisposing factors, initiating factors and perpetuating factors [10]. The dental surgeon, together with a multidisciplinary team involving otolaryngologists and neurologists, should pay attention to the anamnesis as the most important point in the diagnosis, needing special attention to the involvement or not of psychosomatic, emotional factors (anxiety, depression and stress), social factors, as many cases of TMD have emotional substrate [11]. Leeuw (2010), proposed the importance of physical examination in the diagnosis, which consists of palpation of the TMJ, musculature, active movement recognition and joint noise analysis when performed by trained professionals. In addition, the study of sleep (polysomnography) and radiographic images of the TMJ are seen as important auxiliary tools means in the evaluation of the joint [12].

\section{Treatment}

The conservative treatment should be always the first option. Surgical treatment should be considered as the last option, as a small percentage of cases are candidates for this [13]. The choice for the most invasive procedures should be left to cases of failure in results. It is important mentioning the individuality of each case and the patient's close participation in adhering to the treatment imposed by the multidisciplinary team. Recently, there has been a great evolution in results, especially if we consider multidisciplinarity. Procedures such as occlusal adjustment, orthodontics, electrotherapy, botulinum toxin, laser therapy, pharmacological treatment, acupuncture, cryotherapy, heat therapy, muscle relaxant drugs, chiropractic, psychological treatment must be taken in account [13]. The TMJ surgical procedure is indicated in specific cases, such as ankylosis, fractures and certain congenital or developmental disorders. According to Badim et al (2002), the problem is installed in the interarticular disc, which, for some reason, is displaced, causing the clinical picture already mentioned. In these cases, the surgery is limited to removing the articular disc, carefully preserving branches of the facial nerve through its identification aided by a nerve stimulator.8 Damaged structures in the TMJ have a limited capacity for regeneration, as is the case with articular disc cartilage. Stem cell research has shown very promising results in this area with the development of chondrogenic cells [14].

\section{Discussion}

Costen's Syndrome has a high prevalence; epidemiological research has shown that more than $50 \%$ of the population has at least one or more signs of TMD. Due to its wide range of factors, it has not yet been possible to establish a standardized diagnosis [15]. The symptoms of Costen's syndrome go beyond a structural relationship, as it encompasses knowledge from more than one specialty in the health field, thus making diagnosis and treatment with only one professional difficult. According to studies by Costen, temporomandibular disorders (TMD) are completely related to disocclusion, being associated with the loss of the vertical dimension of occlusion [3]. Over time and new studies, it was found that the etiology of TMD is multifactorial, and may cover several factors, such as structural, muscular, or neural origin. The existence of a great diversity of treatments imposes the need for patient exposure on the possibilities of success, as well as the advantages and disadvantages of each method Due to this variability in methods, it is emphasized that each procedure should have its own indication, based on well-defined criteria as well as patient acceptance [16]. 


\section{Conclusion}

As we can see, after decades of the studies initiated by Costen, some etiological factors of TMD remain unclear, requiring further studies. The integration of a multidisciplinary team is essential to confirm the hypotheses raised so far and thus provide quality of life to the patient. With this work we intend to demonstrate that the isolated study of each case, the indication of the correct therapy and the patient's collaboration are of fundamental importance for the success of the treatment. Fortunately, we have a very wide range of techniques and equipment at hand that can bring relief from symptoms as well as restore TMJ function. The treatment of the painful phase, with relative rest of the joint and symptomatic medication, provides pain relief in $90 \%$ of the proposed therapies associating the use of occlusal device, masticatory and cervical therapy and prosthetic rehabilitation showed significant improvements in the symptoms reported by the patient [17]. Surgery should be avoided in cases of bruxism unless psychological treatment has had no effect and the patient remains with the dysfunction [18]. Care with facial innervation (especially the frontal branch) is important. Neuroapraxia (or trauma due to nerve distension) is common, and paralysis of the homologous eyebrow may need a recovery period of up to 6 months. The use of the stimulator has been of enormous value in the identification and preservation of the nerve [8]. In about $85 \%$ of cases there is an emotional factor triggering the pain. Psychobehavioral or psychosocial factors, such as anxiety, stress, and depression, are currently considered as the main etiological factors of TMD [18].

\section{References}

1. Costen JB (1936) Neuralgias and Ears Symptoms associated with disturbed function of the temporomandibular joint. J Amer Med Ass p. 55-57.

2. Quinto AC (1999) Classificação e Tratamento das Disfunções Temporomandibulares: Qual o papel do fonoaudiólogo no tratamento dessas disfunções? [Monografia]. São Paulo: Centro de Especialização em fonoaudiologia clínica p. 23.

3. Costen JB (1934) A syndrome of ear and sinos symptoms dependent upon disturbed function of the temporomandibular joint. Ann Otol Rhinol Laryngol 43: 1-15.
4. Pinto OF (1962) A new structure related to the temporomandibular joint and middle ear. J Prosthet Dent 12(1): 95-103.

5. Ramírez LM, Sandoval GP, Ballesteros LE (2005) Los desordenes temporomandibulares: clinica craneo-cervicofacial referida Temporomandibular disorders: referred cranio-cervico-facial clinic. Med Oral Patol Oral Cir Bucal 10(1): 18-26.

6. Rocha APF, Nardelli MR, Rodrigues MF (2002) Epidemiologia das desordens temporomandibulares: estudo da prevalência da sintomatologia e sua inter-relação com an idade e o sexo dos pacientes. São Paulo Ver Serviço 2(1): 5-9.

7. Barreto DC, Barbosa AR, Frizzo ACF (2010) Relação entre disfunção temporomandibular e alterações auditivas. CECAF 12(6): 1067-1076.

8. Badim J, Xavier RSF (2002) Disfunção da Articulação Temporomandibular (ATM). Rev Bras Cir Plástica 17(1): 51-68.

9. Toledo BAS, Capote TSO, Campos JADB (2008) Associação entre disfunção temporomandibular e depressão. Cienc Odontol Bras 11(4): 75-79.

10. Siqueira JTT, Teixeira MJ (2002) Dor orofacial: Diagnóstico, terapêutica e qualidade de vida. $2^{\text {nd }}$ Ed. São Paulo: Editora Maio.

11. Becker IM (1995) Occlusion as a causative factor in TMD. The New York State Dental Journal 61(9): 54-57.

12. Leeuw R (2010) Dor orofacial: Guia de avaliação, diagnóstico e tratamento. $4^{\text {th }}$ Ed. São Paulo: Quintessence.

13. Michelotti A, Iodice G (2010) The role of orthodontics in temporomandibular disorders. Journal of Oral Rehabil 37(6): 411-429.

14. Johnstone B, Hering TM, Caplan AI, Goldberg VM Yoo JU (1998) In vitro chondrogenesis of bone marrow-derived mesenchymal progenitor cells. Exp Cell Res 238(1): 265-272.

15. Carrara SV, Conti PCR, Juliana SB (2010) Termo do $1^{\text {o }}$ Consenso em Disfunção Temporomandibular e dor Orofacial. Dental Press J Orthod 15(3): 114-120.

16. Mello MA (2005) Correlação entre Sintomas Otológicos e Disfunção Temporomandibular. [Monografia]. Florianópolis: Universidade Federal de Santa Catarina. Especialização em Disfunção Temporomandibular e Dor Orofacial p. 45.

17.Zocoli R, Mota ME, Sommavilla A, Perin LR (2007) Manifestações otológicas nos distúrbios da articulação temporomandibular. ACM 36(1): 90-95.

18. Araneda P, Oyarzo JF, González M, Figueroa C (2013) Intervención psicológica en trastornos temporomandibulares: revisión narrativa. Journal of Oral Research 2(2).

This work is licensed under Creative Commons Attribution 4.0 License DOI: 10.19080/ADOH.2020.12.555846

\section{Your next submission with Juniper Publishers} will reach you the below assets

- Quality Editorial service

- Swift Peer Review

- Reprints availability

- E-prints Service

- Manuscript Podcast for convenient understanding

- Global attainment for your research

- Manuscript accessibility in different formats

( Pdf, E-pub, Full Text, Audio)

- Unceasing customer service

Track the below URL for one-step submission https://juniperpublishers.com/online-submission.php 